\title{
Anticancer drugs of tomorrow: apoptotic pathways as targets for drug design
}

\section{Marek Los, Christof J. Burek, Christopher Stroh, Konrad Benedyk, Hubert Hug and Andrzej Mackiewicz}

Apoptosis or programmed cell death is a set of ordered events that enables the selective removal of cells from tissue and is essential for homeostasis and proper function of multicellular organisms. Components of this signaling network, which include ligands, such as CD95, tumor necrosis factor (TNF) and TNF-related apoptosis-inducing ligand, as well as downstream molecules, such as caspases, Bcl-2 family members, and inhibitor-of-apoptosis proteins, which trigger and regulate apoptosis, are crucial targets for conventional drug development and gene therapy of cancer and other diseases. Here, we focus on apoptotic pathways and propose new potential molecular targets that could prove effective in controlling cell death in the clinical setting.

Marek Los* Christof J. Burek Christopher Stroh Institute of Experimental Dermatology

Röntgenstr. 21

University of Münster D-48149 Münster, Germany

*tel: +492518352943

fax: +492518352250 e-mail: los@uni-muenster.de Konrad Benedyk

Dept of Tumor Biology Oncology Center Maria Sklodowska-Curie

Memorial Institute Wybrzeze Armii Krajowej 15

PL-44100 Gliwice, Poland Hubert Hug TheraSTrat AG Gewerbestrasse 25 $\mathrm{CH}-4123$, Allschwil Switzerland

Andrzej Mackiewicz Dept of Cancer Immunology University of Medical Sciences at Great-Poland Cancer Center Poznan, Poland $\nabla$ Developing a mechanism for the control of cell number was an essential event in the evolution of multicellular organisms. Such a control mechanism is required for organ formation during development, cellular homeostasis in adulthood, and proper function of the immune system (reviewed in [1-3]). Although, in the past, significant attention was focused on the molecular mechanisms that control cell division, recent efforts have exposed an equally elaborate cellular machinery that regulates apoptosis. Components of the apoptosis signaling cascade (including caspases), along with several other triggers and regulators, are among the most promising targets for pharmacological modulation of cell death and inflammation [4-7].

Caspase-1, -4 and -5 are crucial regulators of the secretion of inflammatory cytokines such as IL-1 $\beta$, IL-18 and, indirectly, IFN- $\gamma$ [8-11]. Pharmaceutical companies have therefore focused screening programs on single-caspase or caspase-subfamily-specific inhibitors (Table 1). In addition, modulators of caspase activity are increasingly gaining interest as potential targets for drug development.

In recent years, a family of caspase inhibitors called inhibitor-of-apoptosis proteins (IAPs), which bind and block active caspases, has attracted the attention of the pharmaceutical industry. This interest increased with discovery of the IAP inhibitors, second mitochondriaderived activator of caspase/direct IAP binding protein with low pI (Smac/DIABLO), and heat-inducible serine protease (A2HtrA2), which enable an additional level of apoptosis modulation $[12,13]$. Inhibition of IAPs might facilitate the apoptotic process if their interaction with caspases is prevented. However, when the interaction between IAPs and Smac/DIABLO becomes disrupted, caspases are inhibited, thereby resulting in anti-apoptotic activity [14].

Many tissues and organs - particularly in the immune system - use a receptor-mediated mechanism to activate apoptosis. Several cells express so-called death receptors on their surface. These directly activate caspases and induce apoptosis when stimulated by appropriate ligands (Fig. 1). A subfamily of caspases, termed apical/initiator caspases, become activated upon recruitment to the death-inducing signaling complex (DISC). This is a multiprotein complex formed on the death receptor within seconds or minutes after ligand binding [15]. Once activated, initiator caspases activate downstream/effector caspases and other components of the cell-death machinery $[9,16]$. Modulation of the interactions between 


\section{Table 1. Novel anti-inflammatory and anticancer therapies exploring apoptotic pathways}

\begin{tabular}{|c|c|c|}
\hline $\begin{array}{l}\text { Targeted } \\
\text { molecule(s) }\end{array}$ & $\begin{array}{l}\text { Principle/ } \\
\text { compound }\end{array}$ & $\begin{array}{l}\text { Company or } \\
\text { Research Inst. }\end{array}$ \\
\hline TRAIL-R1 (DR-4) & $\begin{array}{l}\text { Activatory, single- } \\
\text { chain monoclonal } \\
\text { antibody against } \\
\text { TRAIL-R1 }\end{array}$ & $\begin{array}{l}\text { Cambridge } \\
\text { Antibody } \\
\text { Technology } \\
\text { Group }\end{array}$ \\
\hline
\end{tabular}

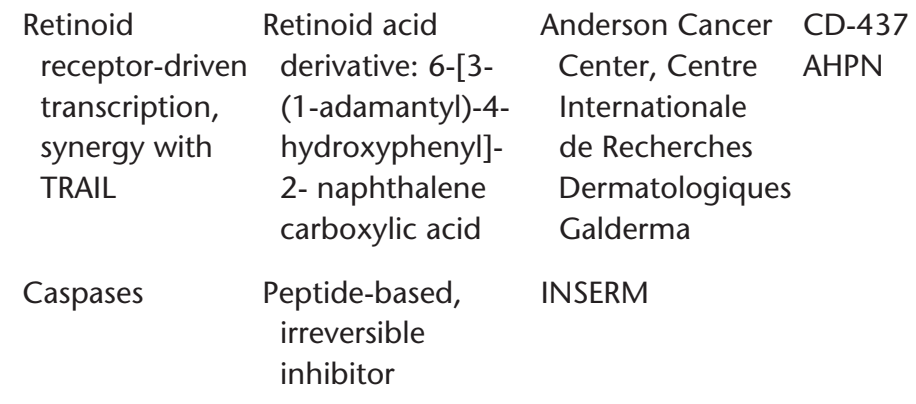

\begin{tabular}{|c|c|c|}
\hline Caspases & Caspase inhibitor & $\begin{array}{l}\text { Idun } \\
\text { Pharmaceuticals }\end{array}$ \\
\hline Caspases & $\begin{array}{l}\text { Caspase inhibitor } \\
\text { N-[(1,3- } \\
\text { dimethylindole-2- } \\
\text { carbonyl)valinyl]- } \\
\text { 3-amino-4-oxo-5- } \\
\text { fluoropentanoic } \\
\text { acid }\end{array}$ & $\begin{array}{l}\text { Idun } \\
\text { Pharmaceuticals }\end{array}$ \\
\hline
\end{tabular}

\begin{tabular}{|c|c|c|}
\hline Caspases & $\begin{array}{l}\text { Caspase inhibitor, } \\
\text { preference } \\
\text { towards caspase- } 8\end{array}$ & $\begin{array}{l}\text { Maxim } \\
\text { Pharmaceuticals }\end{array}$ \\
\hline
\end{tabular}

Caspases

Caspase inhibitor Vertex

Pharmaceuticals

Caspases Caspase inhibitor Merck Frosst

Caspase-3 Highly selective Merck Frosst caspase-3 inhibitor

\section{Code or Advancement \\ Brand Name}

TI-1, TI-2 Application of anti-TRAIL receptor 1 (TRAIL-R1) scFv monoclonal antibodies (TrailR-mAb) for the potential treatment of human cancers

Six lead mAbs were identified and shown to induce apoptosis in tumor cell lines expressing TRAIL-R1, with IC $\mathrm{C}_{50}$ values in the range of 1.5-73 $\mathrm{nM}$. The two most potent antibodies identified, TI-1 and TI-2, had IC ${ }_{50}$ values of 3.4 and $1.5 \mathrm{~nm}$, respectively.

Mitochondria and caspase- 3 dependent apoptosis

Increases expression of Bad and down-regulates Bcl-2 expression

Synergy effect between recombinant TRAIL and CD-437 observed in several cancer cell lines and in human tumor xenografts

In a rat model a broad spectrum caspase inhibitor, zVADfmk (dose $3 \mathrm{mg} \mathrm{kg}^{-1}$, iv), when co-injected with endotoxin, completely prevented endotoxin-induced myocardial dysfunction evaluated at $4 \mathrm{~h}$ and $14 \mathrm{~h}$ following endotoxin challenge

IDN-5370 Protective towards apoptosis induction in cortical- and synaptic neurons

Reduces infarct size in a rodent cardiac ischemia/ reperfusion model by more than $50 \%$

IDN-1965 $\mathrm{ED}_{50}$ by ip administration is $0.14 \mathrm{mg} \mathrm{kg}^{-1}$, by iv administration is $0.04 \mathrm{mg} \mathrm{kg}^{-1}$ and by oral administration is $1.2 \mathrm{mg} \mathrm{kg}^{-1}$

Protects from anti-CD95-induced death and liver damage in murine system [91]

Increased survival in a Gaq-40 transgenic mouse model of heart failure (left ventricular hypertrophy, left ventricular dysfunction)

All treated animals showed improved fractional shortening and reduced left ventricular end-diastolic diameter compared with control, placebo-treated animals

Animal study demonstrate protection of liver cells from TNF- or galactosamine-induced apoptosis in a murine model [92]

VX-799 A potent small molecule caspase inhibitor, VX-799 was very effective in several animal models of bacterial sepsis Clinical trials in preparation

M-920 Strongly reduces mortality ( $80 \%)$ in a murine and rat $(\mathrm{L}-826,920)$ sepsis model by preventing from sepsis-related apoptosis of B- and T-cells [45]

MF-286 and Highly-selective caspase-3 dipeptide-inhibitor, based on MF-867 valyl-homoglycine-benzylmercaptoacetylketone, $\mathrm{IC}_{50}$ value: $6 \mathrm{nM}, 38$-fold selectivity over caspase-7 and more than a 1000-fold selectivity over other caspases $\mathrm{IC}_{50}$ value in whole cells: of 0.5 to $1.6 \mu \mathrm{M}$ 
Table 1. Continued

\begin{tabular}{|c|c|c|c|c|}
\hline $\begin{array}{l}\text { Targeted } \\
\text { molecule(s) }\end{array}$ & $\begin{array}{l}\text { Principle/ } \\
\text { compound }\end{array}$ & $\begin{array}{l}\text { Company or } \\
\text { Research Inst. }\end{array}$ & $\begin{array}{l}\text { Code or } \\
\text { Brand Name }\end{array}$ & $\begin{array}{l}\text { Advancement } \\
\text { e }\end{array}$ \\
\hline Caspase-3 & $\begin{array}{l}\text { Highly selective } \\
\text { caspase-3 } \\
\text { inhibitor }\end{array}$ & Merck Frosst & $\begin{array}{l}M-791 \\
(L-826,791)\end{array}$ & $\begin{array}{l}\text { Strongly reduces mortality }(\sim 80 \%) \text { in a murine and rat } \\
\text { sepsis model by preventing from sepsis-related apoptosis } \\
\text { of B- and T-cells [45] }\end{array}$ \\
\hline Caspase-1, -4 & $\begin{array}{l}\text { Selective inhibitor } \\
\text { originated from } \\
\text { specific substrate } \\
\text { peptide motif }\end{array}$ & $\begin{array}{l}\text { Vertex } \\
\text { Pharmaceuticals } \\
\text { Aventis Pharma } \\
\text { AG }\end{array}$ & $\begin{array}{l}\text { Pralnacasan } \\
\text { VX-740, } \\
\text { HMR-3480 }\end{array}$ & $\begin{array}{l}\text { In a Type II collagen-induced rat rheumatoid arthritis } \\
\text { model, pralnacasan is effective at } 50 \mathrm{mg} / \mathrm{kg} \text { bid, for over } \\
60 \text { days; well tolerated in animal models [93] } \\
\text { Encouraging results in Phase I clinical studies, currently in } \\
\text { Phase II trials for rheumatoid arthritis treatment }\end{array}$ \\
\hline Caspase-3 & $\begin{array}{l}\text { Recombinant } \\
\text { caspase- } 3 \text { linked } \\
\text { to an antibody }\end{array}$ & Immunex & & $\begin{array}{l}\text { Recombinant caspase- } 3 \text { linked to the antibody Herceptin } \\
\text { (Genentech) tested in animal tumor model }\end{array}$ \\
\hline Caspases & Caspase activator & $\begin{array}{l}\text { Maxim } \\
\text { Pharmaceuticals }\end{array}$ & MX-2060 & $\begin{array}{l}\text { 'Small molecule' caspase activator, a potential anticancer } \\
\text { agent } \\
\text { Tested in human cancer xenograft animal models }\end{array}$ \\
\hline Caspase-3 & $\begin{array}{l}\text { Selective } \\
\text { activation } \\
\text { of caspase-3 }\end{array}$ & Merck Frosst & & $\begin{array}{l}\text { Caspase- } 3 \text { zymogen is maintained in an inactive } \\
\text { conformation by a regulatory triple Asp-motif, so called } \\
\text { "safety-catch", localized within a flexible loop near the } \\
\text { large-subunit/small-subunit junction [34] } \\
\text { The inhibitory mechanism depends on electrostatic } \\
\text { interaction } \\
\text { Screen for 'small molecules' capable of disrupting the } \\
\text { interaction is in progress }\end{array}$ \\
\hline $\mathrm{Bcl}-2$ & $\begin{array}{l}\text { Antisense } \\
\text { 18-mer- } \\
\text { oligonucleotide, } \\
\text { (Phosphorothioate) }\end{array}$ & Genta & $\begin{array}{l}\text { G-3139, } \\
\text { Genasense }\end{array}$ & $\begin{array}{l}\text { Promising results in combination with a standard } \\
\text { chemotherapy [94] } \\
\text { Phase I/II studies of Genasense have demonstrated an } \\
\text { excellent safety profile with toxicity observed in } 20 \% \text { of } \\
\text { patients, fatigue in } 10 \% \text { and rash in } 5 \% \text {, the symptoms } \\
\text { reverse upon withdrawal of treatment } \\
\text { In Phase III trials for malignant melanoma [59] }\end{array}$ \\
\hline Cdc25 & Cdc25-inhibitor & $\begin{array}{l}\text { Maxia } \\
\text { Pharmaceuticals }\end{array}$ & MX-7091 & $\begin{array}{l}\text { Regression of breast cancer tumors in animal models } \\
\text { Phase I clinical trials in preparation }\end{array}$ \\
\hline Survivin & $\begin{array}{l}\text { Antisense } \\
\text { oligodeoxy- } \\
\text { nucleotides }\end{array}$ & $\begin{array}{l}\text { Isis } \\
\text { Pharmaceuticals/ } \\
\text { Abbott } \\
\text { Laboratories }\end{array}$ & & $\begin{array}{l}\text { Following transfection of antisense oligonucleotides to } \\
\text { mouse survivin mRNA, a time- and dose-dependent } \\
\text { increase in polyploidy of approx. 2- to 3-fold and } \\
\text { induction of apoptosis were observed in most of the } \\
\text { tumor cell lines [89] }\end{array}$ \\
\hline Smac/DIABLO & $\begin{array}{l}\text { Exclusive rights } \\
\text { patented }\end{array}$ & $\begin{array}{l}\text { Idun } \\
\text { Pharmaceuticals }\end{array}$ & & $\begin{array}{l}\text { Exclusive rights to develop Smac-based therapy have been } \\
\text { patented } \\
\text { Screening program focusing on Smac modulators have } \\
\text { been started }\end{array}$ \\
\hline 26S Proteasome & $\begin{array}{l}\text { Proteasome } \\
\text { inhibition } \\
\text { Dipeptide boronic } \\
\text { acid }\end{array}$ & $\begin{array}{l}\text { Millennium } \\
\text { Pharmaceuticals }\end{array}$ & PS-341 & $\begin{array}{l}\text { Transient inhibition of the proteasome induces selective } \\
\text { apoptosis in cancer cells [95] } \\
\text { PS-341 was well tolerated and had significant single and } \\
\text { combination antitumor activity for several cancers } \\
\text { Phase II clinical trials against multiple myeloma and in } \\
\text { malignancies with multiple drug resistance } \\
\text { Significant antiangiogenic activity }\end{array}$ \\
\hline
\end{tabular}




\section{Table 1. Continued}

\begin{tabular}{|c|c|c|c|c|}
\hline $\begin{array}{l}\text { Targeted } \\
\text { molecule(s) }\end{array}$ & $\begin{array}{l}\text { Principle/ } \\
\text { compound }\end{array}$ & $\begin{array}{l}\text { Company or } \\
\text { Research Inst. }\end{array}$ & $\begin{array}{l}\text { Code or } \\
\text { Brand Name }\end{array}$ & Advancement \\
\hline \multirow[t]{4}{*}{$\begin{array}{l}\text { C-Abl, c-kit, } \\
\text { PDGF-R- } \\
\text { tyrosine kinase }\end{array}$} & $\begin{array}{l}\text { Inhibitor of Bcr- } \\
\text { Abl, c-kit and } \\
\text { PDGF-R-tyrosine } \\
\text { kinase }\end{array}$ & Novartis AG & STI-571 & $\begin{array}{l}\text { Induced remission of chronic myelogenous leukemia (CML) } \\
\text { in } \sim 52 \% \text { of patients [96] }\end{array}$ \\
\hline & $\begin{array}{l}\text { 'Small molecule' } \\
\text { selectively toxic } \\
\text { for transformed } \\
\text { cells }\end{array}$ & $\begin{array}{l}\text { Gemin X } \\
\text { Biotechnologies }\end{array}$ & GX-01 & $\begin{array}{l}\text { A series of small molecules that selectively induce apoptosis } \\
\text { in cancer cells } \\
\text { GX-01's action requires the presence of oncogenic changes } \\
\text { in the cell } \\
\text { In an in vivo study GX-01 compounds significantly improve } \\
\text { the survival of mice bearing ovarian tumors }\end{array}$ \\
\hline & $\begin{array}{l}\text { A viral death- } \\
\text { protein selectively } \\
\text { toxic for } \\
\text { transformed cells }\end{array}$ & $\begin{array}{l}\text { Gemin X } \\
\text { Biotechnologies }\end{array}$ & E4orf4 & $\begin{array}{l}\text { Viral death protein that selectively induces apoptosis in } \\
\text { several types of cancer cells in vitro and significantly slows } \\
\text { down tumor growth in mice (human lung and cervical } \\
\text { tumor xenografts) [97] } \\
\text { Kills a wide range of human tumor cells, regardless of } \\
\text { p53 status }\end{array}$ \\
\hline & $\begin{array}{l}\text { A bisindolyl- } \\
\text { maleimide, that } \\
\text { induces M-phase } \\
\text { arrest and } \\
\text { apoptosis. }\end{array}$ & $\begin{array}{l}\text { Hoffmann-La } \\
\text { Roche }\end{array}$ & $\begin{array}{c}\text { Ro-31- } \\
7453\end{array}$ & $\begin{array}{l}\text { Induced M-phase arrest and apoptosis } \\
\text { In Phase II clinical studies as single agent therapy or in } \\
\text { combination with other chemotherapeutics } \\
\text { Can be given orally or iv. } \\
\text { Myelosuppression and mucositis and secretory diarrhoea } \\
\text { upon prolonged venous infusion; neutropenia upon } \\
\text { bolus application }\end{array}$ \\
\hline
\end{tabular}

Abbreviations: ip, intraperitoneally; iv, intravenously.

Cambridge Antibody Technology Group (http://www.cambridgeantibody.com); Anderson Cancer Center (http://www.mdanderson.org); Idun Pharmaceuticals (http://www.idun.com); Maxim Pharmaceuticals (http://www.maxim.com); Vertex Pharmaceuticals (http://www.vertex.com); Merck Frosst (http://www.merckfrosst.ca); Aventis Pharma AG (http://www.aventis.com); Genentech (http://www.gene.com); Immunex (http://www.immunex.com); Maxia Pharmaceuticals (http://www.maxia.com); Isis Pharmaceuticals (http://www.isip.com); Abbott Laboratories (http://www.abbott.com); Millennium Pharmaceuticals (http://www.mlnm.com); Novartis AG (http://www.novartis.com); Gemin X Biotechnologies (http://www.geminx.com); Hoffmann-La Roche (http://www.roche.com); CIRD Galderma (http://www.galderma.com); INSERM (http://www.inserm.fr)

DISC components, or triggering of death receptors by naturally occurring or artificial ligands, might enable cell death to be controlled for therapeutic purposes. This review discusses various components of the apoptotic machinery as potential targets for the development of therapeutic strategies.

\section{Receptor-triggered apoptosis: perspectives and limits}

Previous approaches to cancer therapy in mice, using either tumor necrosis factor (TNF) or CD95L - both members of the death-ligand family - have failed owing to severe systemic toxicity and hepatotoxicity, respectively. Recently, another death-ligand family member, TNF-related apoptosis -inducing ligand (TRAIL) has been cloned and characterized [17]. Several promising studies have reported that TRAIL potently induces apoptosis in transformed or virally infected cells, but has little or no detectable cytotoxic effects in normal and non-transformed cells. Moreover, no overall toxicity was observed during in vivo studies in mice and monkeys $[18,19]$. Preclinical safety studies in primates (cynomolgus monkeys) showed no adverse reactions even after the administration of substantial doses of recombinant TRAIL (10 $\mathrm{mg} \mathrm{kg}^{-1} \mathrm{day}^{-1}$ ) [19]. The severe liver toxicity (massive hemorrhagic liver necrosis) that halted the in vivo testing of CD95L and TNF was not observed with the TRAIL treatment.

An important feature of TRAIL treatment is an apparent strong synergistic effect when combined with anticancer drugs or irradiation. The potentiation of cytotoxicity is most apparent in tumor cells that do not respond to treatment with either agent alone. The specific details of the underlying mechanism(s) of the potentiating effect are not known. However, they might include: (1) transcriptional induction of death receptor-4- (DR4) and DR5-TRAIL receptors (DR4-TRAIL-R1 and DR5-TRAIL-R2); (2) reduced expression of apoptosis-inhibitory molecules such as Bcl-2, 
Bcl- $\mathrm{X}_{\mathrm{L}}$ or c-FLICE-inhibitory protein (c-FLIP); and (3) upregulation of proapoptotic proteins such as caspase-8, FADD, Smac and HtrA2. Malignancies such as acute leukemia, breast cancer, colon cancer, lung cancer and melanoma, among other malignant proliferative disorders that do not respond to standard treatment, regained sensitivity when supplemented with TRAIL [20-25].

An interesting, novel mechanismof-action underlies the synergistic effect of all-trans retinoid acid (and its derivatives), combined with TRAIL (Table 1). 6-[3-(1-adamantyl)-4hydroxyphenyl]-2-naphthalene carboxylic acid (also known as CD-437) not only synergizes with TRAIL, but also induces its expression, thus killing target cells in a TRAIL-autocrine or -paracrine manner [26]. The synergistic effects of TRAIL and retinoids have been shown in several malignancies including acute leukemia, lung cancer and prostate cancer $[24,27,28]$. However, concerns were raised following a study reporting that some primary cells, particularly hepatocytes, were sensitive to TRAIL [29]. However, this appears to depend on both the way the recombinant protein was engineered and the way the primary cells were prepared. Although the data from clinical studies using TRAIL are not available yet, the in vitro and animal experiments show the significant therapeutic potential of this molecule.

\section{Caspases: modulators of apoptosis and cytokine maturation}

Mammalian caspases form a large family comprising at least 12 members. They can be divided into subfamilies having distinct roles in cell (patho)physiology based on their differential substrate specificity, structural differences of their zymogens, preferred cellular localization, and known roles in cellular processes. As they can proteolytically cleave selected cellular proteins, apoptosis is irreversible [16,30-32]. Some caspases, including caspase-1, -4 and -5 , function primarily as cytokine activators.

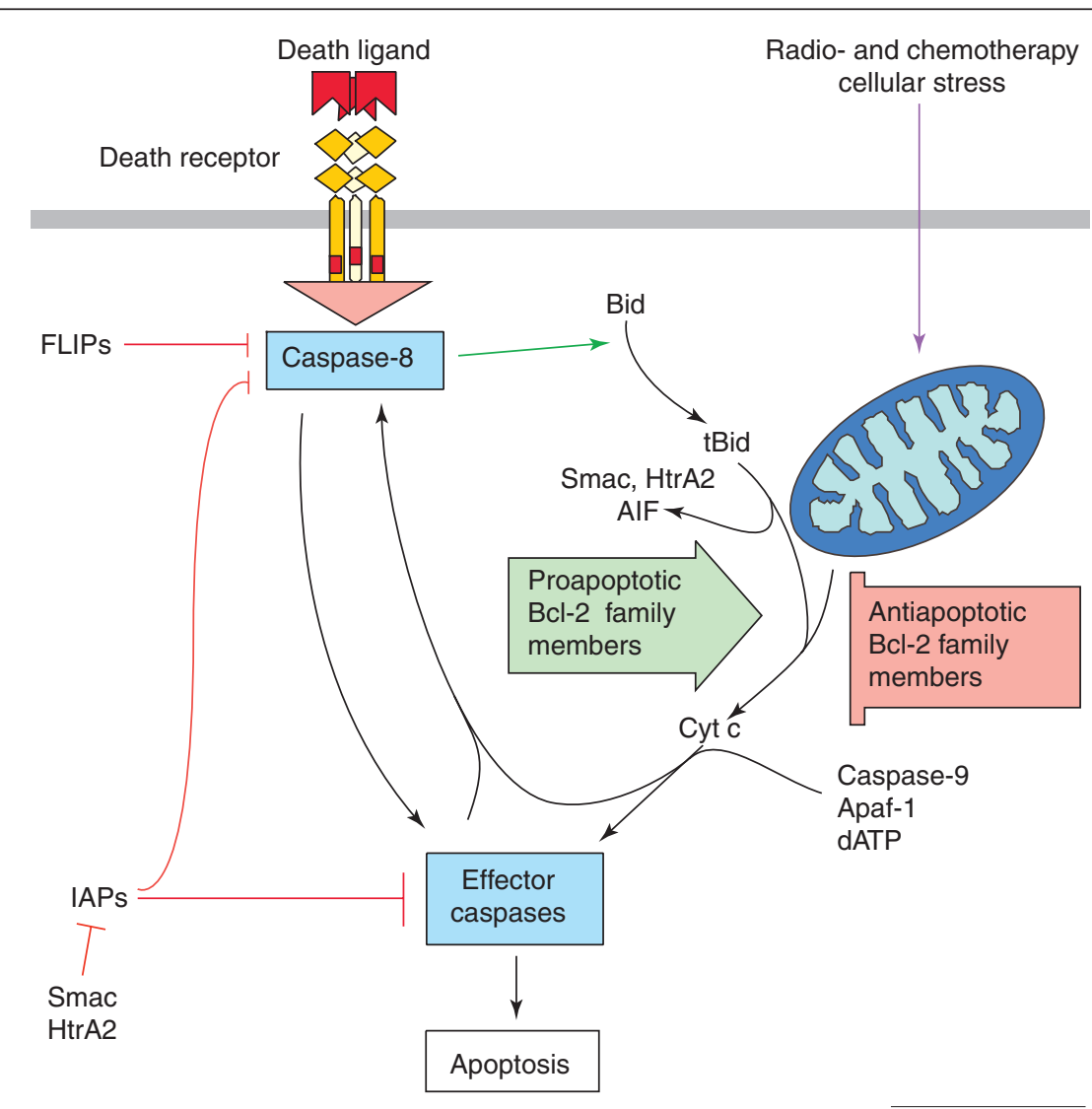

$\overline{\text { Drug Discovery Today }}$

Figure 1. Apoptotic pathways are potential targets for therapeutic modulation. The main, best -characterized apoptotic pathways are shown. Triggering of a death receptor (left) by an agonistic antibody or natural ligand leads to the recruitment of the adapter protein FADD and pro-caspase-8, which becomes cleaved and activated at the receptor complex, initiating the caspase cascade. The mitochondria-apoptosome intrinsic pathway (right) is triggered by several apoptotic stimuli. An early step, which is currently poorly understood, is the mitochondrial release of apoptosis-inducing molecules [e.g. cytochrome c, apoptosis-inducing factor (AIF), heat-inducible serine protease A2 (HtrA2), and second mitochondria-derived activator of caspase/direct inhibitor-of-apoptosis protein binding protein with low pl (Smac/DIABLO)] into the cytosol. Initially, cytochrome $\mathrm{c}$ and dATP associate with Apaf1. This process unmasks the caspase activating recruitment domain (CARD) motif in Apaf1, enabling the binding and activation of pro-caspase-9. Once activated, caspase- 9 activates other members of the caspase cascade. A proteolytic cleavage cascade significantly amplifies the initial signal. In addition, positive-feedback loops involving Bid, mitochondria, apoptosome, caspase-9, effector caspases and caspase8 are also able to amplify the death signal. The apoptosome pathway is further potentiated by AIF through the increased mitochondrial release of cytochrome $\mathrm{c}$ and pro-caspase- 9 . Negative modulators of apoptosis, such as FLICE-inhibitory proteins (FLIPs) and inhibitorof-apoptosis proteins (IAPs), negatively influence the transmission of the apoptotic signal and are thus important targets for novel anticancer therapies. Smac/DIABLO and HtrA2 halt the apoptosis-inhibitory action of IAPs. 
under circumstances when shutting-off the cellular transcription and translation machinery is a powerful defense mechanism by itself. In addition to their well-established role in cell death and cytokine maturation, there is some evidence that caspases might be involved in other crucial cellular processes, including activation, differentiation, and cell-cycle progression [33]. Although these areas of caspase action still remain to be defined, they could be responsible for the unexpected effects observed in the pharmacological targeting of caspases.

Modulators of caspase activity are currently the focus of both commercial and academic research (Table 1). Discovering selective inhibitors of inflammatory-caspases (caspase-1, -4 and -5) might help to control various autoimmuno-aggressive diseases, such as rheumatoid arthritis, as well as acute life-threatening conditions such as sepsis. Inhibition of apoptotic caspases might help to slow-down or even stop the progression of degenerative diseases such as Alzheimer's or spinal lateral sclerosis. By contrast, selective activation of caspases, or at least lowering the activation threshold, might help to combat cancer and eradicate some chronic viral infections. As indicated in Table 1, caspases are by far the most popular targets for the development of drugs that potentially modulate the apoptotic process. Caspase-3, the key effector caspase in apoptosis, is inhibited by an intramolecular electrostatic interaction, facilitated by a stretch of three aspartic acid molecules, termed the 'safety-catch' [34]. This discovery raises hope for the rapid development of small pharmacologically active molecules capable of lowering the threshold of activation, or even activating the caspase on its own.

Significant advancements have been made in the search for specific caspase inhibitors. Proof-of-principle experimental data in animal models indicate that caspase inhibition improves various conditions, including myocardial infarct (Table 1) or stroke-related ischemia/reperfusion injury of the brain, liver and other organs [35-37]. This protective effect is at least in part related to the limitation of the inflammatory response by caspase inhibition [38,39]. Efforts to design inhibitors that control the subfamily of inflammatory caspases were undertaken long before the role of caspases in apoptosis was known. Gene-disruption experiments in mice confirmed the role of mouse caspase- 1 and -11 (the latter is the mouse homolog of human caspase-4 and -5) in the propagation of the acute inflammatory response that relies on IL-1 $\beta$ and other cytokines [40,41]. Caspase$1^{(-)-)}$mice have a major defect in the production of mature IL-1 $\beta$ and impaired IL- $1 \alpha$ synthesis. Secretion of TNF and IL-6 in response to lipopolysaccharide (LPS) stimulation was also diminished in targeted animals. In addition, macrophages from caspase- $1^{(-)}$mice are defective in
LPS-induced IFN- $\gamma$ production [42] owing to their inability to secrete mature IL-18. The mice are also highly resistant to lethal doses of endotoxin [43]. A corresponding phenotype was observed by caspase-11(-/-) mice [44]. The proinflammatory role of caspase- 1 was strengthened by the finding that pharmacological blockage or genetic deletion of caspase-1 decreased necrosis, edema formation, and serum levels of amylase and lipase (both enzymes are indicators of pancreatic damage) during experimentally induced pancreatitis [44].

Caspase inhibitors were also highly protective in a sepsis model (cecal ligation and puncture) in both mouse and rat [45]. Treatment with either the broad-spectrum caspase inhibitor M-920 or the caspase-3-specific M-791 (both developed by the Merck Frosst Center; http://www. merckfrosst.ca) resulted in an equally protective response for the two molecules. Both inhibitors protected 80-90\% of animals, whereas only $10-20 \%$ of control animals (treated with either solvent or the inactive molecule) survived the experiment. The protective effect can probably be attributed to the prevention of sepsis-related death of $\mathrm{T}$ - and B-cells undergoing apoptosis during sepsis [46,47].

\section{Mitochondrial death pathway: pro- and anti- apoptotic $\mathrm{BCl}-2$ family members as drug targets}

Bcl-2 was the first apoptosis inhibitor to be discovered, and its potential oncogenic function was evident from frequent amplified expression in lymphomas $[48,49]$. Since then, more family members have been cloned and characterized [50-53]. The family comprises both anti-apoptotic proteins (e.g. Bcl-2 and Bcl- $\mathrm{X}_{\mathrm{L}}$ ) and pro-apoptotic proteins (e.g. Bax and Bid) (Fig. 1). In healthy cells, both subfamilies remain in equilibrium. Anti-apoptotic Bcl-2 family members inhibit cell death by blocking cytochrome c release from mitochondria [54,55], thereby preventing activation of the apoptosome pathway. By contrast, Bax and a truncated form of Bid induce both cytochrome c release and caspase activation in vitro [56] and in vivo [57]. Overexpression of Bcl-2 could provide a survival advantage for cancer cells and has been associated with increased frequency of lymphoma development in a mouse model [49]. Loss of the pro-apoptotic protein Bax function might play a role in the pathogenesis of colorectal cancers [58].

Mitochondrial cytochrome c release frequently occurs following the induction of apoptosis by chemotherapy, radiation and most other death stimuli. Together with (d)ATP, pro-caspase-9, and Apaf-1, cytochrome c contributes to apoptosome formation and subsequent activation of caspases (Fig. 1). Bcl-2 prevents cytochrome c release, thereby blocking cell death, and is therefore a suitable target for the development of anticancer therapies. Bcl-2 is 
frequently overexpressed in various malignancies, most commonly in a group of B-cell non-Hodgkin's lymphomas that have at $(14 ; 18)$ chromosomal translocation.

\section{Targeting $\mathrm{BCl}-2$ by antisense strategy}

Modulation of $\mathrm{Bcl}-2$ expression is in the most advanced stage of drug development compared with all other apoptosis-based approaches. Genta (http://www.genta.com/) has designed several antisense sequences targeting different parts of the gene encoding Bcl-2, thus inhibiting its expression to varying degrees. Genasense (Table 1), the most promising antisense phosphorothioate, is highly specific for Bcl-2 mRNA. In preclinical studies using human xenografts in a severe combined immunodeficiency (SCID) mouse lymphoma model, Genasense was more effective than Cytoxan (Bristol-Myers Squibb; http://www.bristol-myers. com), the drug used in the treatment of lymphoma. A combination of Genasense with Cytoxan significantly potentiated the efficacy of treatment. Similar results were obtained in other studies where Genasense was combined with Taxetir (Bristol-Myers Squibb; http://www.bristol-myers. com) - currently the most effective drug for the treatment of breast cancer - in nude mice bearing xenografts of human breast cancer. Taxetir and Genasense were equally effective in prolonging the lifespan of the mice; moreover, a combination of the two drugs led to full remission of the tumor in all treated mice. These animals remained tumor free for at least 180 days, compared with control animals, which died at around day 10 .

In a model of human melanoma xenografted into nude mice, Genasense in combination with dacarbazine (DTIC; Boehringer-Ingelheim; http://www.boehringeringelheim.de) halted tumor growth, whereas DTIC alone had a weaker effect. Genasense treatment has demonstrated a biological response in Phase-I and -II clinical trials. The most promising data were obtained from patients with lymphoma, where a sustained and complete reversal of the disease was demonstrated. One patient with an advanced stage of lymphoma showed complete remission following 18 months of treatment. In addition, Genasense effectively decreased Bcl-2 protein expression in melanoma tumors and, combined with chemotherapy, induced partial remission of late-stage melanomas. In a study of 25 patients with advanced-stage melanoma, and with a life expectancy of $<6$ months, all patients responded to a combination of standard therapy and treatment with Genasense; life expectancy increased to $\sim 17$ months. Patients with acute myeloid leukemia also responded well to Genasense; Bcl-2 was virtually eliminated after 5-7 days of treatment. Subsequent treatment with conventional chemotherapy resulted in complete remission.
In one bladder-cancer patient who was particularly resistant to chemotherapy, a single treatment of Genasense resulted in a reduction of tumor size. Phase-I and -II studies of Genasense have shown good safety profiles, with minor toxicity restricted to $<20 \%$ of patients $[59,60]$.

\section{$D-R N A i$}

Another promising gene-regulatory approach is mRNAantisense DNA interference (D-RNAi) - a novel post-transcriptional mechanism that silences gene expression by transfection of mRNA-antisense-DNA hybrids. Highly potent and sustained inhibition of Bcl-2 expression was observed in human prostate cancer LNCaP cells, the human CD4(+) T-cell line H9, as well as in chicken embryos [61]. Moreover, the D-RNAi-based strategy inhibited HIV-1 replication in an experimental system using HIV-1 viral gene expression. D-RNAi was found to have long-term gene-knockout effects resulting from a post-transcriptional gene silencing mechanism that might involve the homologous recombination of intracellular mRNA and the mRNA components of a D-RNAi construct [62]. Thus, D-RNAi is another potential strategy that enables the development of novel therapeutics against cancer and viral infections.

\section{Limitations of BCl-2 family-based therapies}

The application of antisense-based therapies is limited to tumors outside the CNS. Oligonucleotides are unable to cross the blood-brain barrier and therefore cannot be used to treat brain metastases and brain tumors. In addition, clinical studies only partially support the negative prognostic value of Bcl-2 overexpression in hematological malignancies or solid tumors [63]; the probable reason is the influence of $\mathrm{Bcl}-2$ family members on cell proliferation. Bcl-2 is phosphorylated at the G2-M transition and delays the re-entry of resting NIH-3T3 cells into the cell cycle [64]. Moreover, Bcl-2 transgenic mice have impaired T-cell proliferation, whereas transgenic overexpression of Bax accelerates cell-cycle progression and apoptosis $[64,65]$. Cells overexpressing Bcl-2 also have decreased levels of phosphorylated retinoblastoma protein - the key regulator of the G1 checkpoint [66]. In addition, downregulation of Bcl-2 by antisense approaches enhances proliferation of acute myeloid leukemia cells [67]. Moreover, mutations that suppress the anti-apoptotic activity of Bcl-2 also prevent inhibitory effects on cellcycle transition, indicating that these two activities of Bcl-2 involve partially overlapping pathways $[33,64,68]$. Large-scale phase III clinical trials of Genasense and related antisense-based approaches will certainly pinpoint the clinical relevance of the Bcl-2 family members in oncogenesis. 


\section{Targeting the Bcl-2 family by small molecules}

The bioavailability problems of antisense- or D-RNAi-based therapeutics could be overcome by small molecules that either target crucial protein-protein interactions or mimic certain protein domains. BH3-domains of Bcl-2 family proteins are perfect candidates for this approach owing to their small size ( 10 amino acids). Several in silico lead molecules have been discovered based on crystallography data $[69,70]$. However, subsequent verification experiments using wet-screen or cellular assays only partially supported the potential of this approach for fast and reliable drug discovery $[71,72]$.

\section{IAPs, Smac/DIABLO and Omi/HtrA2: modulation of the advancing apoptotic process}

Activation of caspases in a cell is not equal to the induction of apoptosis. Regulatory and effector functions of caspases during erythropoesis and cytokine maturation indicate the presence of active caspases in cells under physiological conditions $[3,33,73]$. The quantity and cellular localization of caspases, and the abundance of their specific inhibitors probably determines the fate of the cell.

A significant amount of attention has been given to IAPs, a family of molecules that contain baculoviral repeat (BIR) domains and, in some cases, a zinc RING-finger domain [74]. The family members - X-linked IAP (XIAP), Livin/ML-IAP, cIAP-1 and CIAP-2 - are thought to inhibit apoptosis through direct interaction with caspases, although some of these proteins are also involved in additional signaling pathways $[75,76]$. The most potent of these caspase inhibitors, XIAP, selectively inhibits one of the active forms of caspase-9 (p35-p12 heterotetramer) through an interaction involving its BIR3 domain and the small subunit (p12) of caspase-9. By contrast, the BIR2 domain of XIAP, along with a few crucial adjacent residues, is required to inhibit active caspase- 3 and $-7[14,77,78]$. Thus, XIAP interferes with death receptor- and apoptosome-mediated apoptosis by inhibiting both initiator and effector caspases.

The activity of IAPs is regulated by Smac/DIABLO, which is a structural homolog of the Drosophila proteins, Reaper, Hid and Grim $[79,80]$. In a similar way to cytochrome c, this protein is released into the cytosol during the early stages of apoptosis and activates caspases by inhibiting IAPs, particularly XIAP. Smac does not resemble any mammalian protein with known function and represents a novel apoptosis regulator. Upon overexpression, it sensitizes cells towards death stimuli [12]. Research programs aimed at identifying molecules that mimic Smac are in only early stages (Table 1). Nevertheless, owing to the relatively low molecular mass of Smac $(24 \mathrm{kD})$, and its relatively small interaction surface with IAPs, screening programs for pharmacologically active small molecules could soon fulfill expectations [81].

The development of an IAP-based anticancer strategy could be more challenging than for Smac. Inhibitor-ofapoptosis proteins are the broadest caspase inhibitors in the cell, but also the most heterogeneous. So far, eight human IAP family members are known, most of which contain more than one BIR-domain. Collectively, they contain a total of 16 inhibitory BIR-domains. Therefore, it would be almost impossible to target all of the domains with a single small-molecule inhibitor. However, the differential, tissue-specific expression pattern of IAPs offer the possibility of selective, tissue-specific modulation of caspase activity. For example, IAP-inhibiting molecules that do not target neuronal apoptosis inhibitory protein (NAIP or neuronal IAP) would be less toxic to the CNS. Alternatively, careful engineering of antisense molecules that target conserved sequences of BIRs could lead to the development of global inhibitors of IAP expression.

Another mitochondrial protein, Omi/HtrA2, which can bind and inhibit XIAP has recently been identified $[82,83]$. Omi is a mitochondria-localized serine protease. During apoptosis, Omi is released from mitochondria and inhibits the function of XIAP in a similar way to Smac. Binding of Smac and Omi can antagonize the binding of XIAP to caspase- 9 and thereby modulate the caspase cleavage activity of the apoptosome. The magnitude of the apoptotic stimulus, as well as the cellular levels of Smac, Omi, XIAP and other as-yet unidentified proteins, might contribute to the sensitivity of a particular cell type to apoptosis. Thus, Omi is also a promising target for the pharmacological modulation of apoptosis.

Significant attention has also been given to survivin (Table 1), another IAP-family member that has been found to inhibit cell death by binding to caspases and the proapoptotic Smac $[79,84]$. Survivin is specifically expressed in the late G2-phase and the M-phase of the cell cycle and appears to function as both a cell-cycle regulator and an apoptosis suppressor [85]. At the start of mitosis, survivin associates with microtubules of the mitotic spindle apparatus. Interestingly, caspase-3 and the cyclin-dependent kinase inhibitor $\mathrm{p} 21^{\text {Waf1 }}$ also co-localize with survivin at the centrosomes. Interfering with survivin function induces caspase- 3 activity and apoptosis, producing a defect characterized by hyperploidy, multinucleation, and supernumerary centrosomes [85]. The role of survivin in the inhibition of apoptosis was recently challenged by a group who claim that it primarily functions in mitosis [86]. Indeed, survivin-like proteins that play a role exclusively 
in karyokinesis have been identified in yeasts and C. elegans. Several of these genes show similar intron-exon structure, particularly around the BIR-encoding sequences $[87,88]$. Nevertheless, regardless of whether survivin functions as a caspase inhibitor in addition to controlling karyokinesis-related events, its downregulation would certainly affect the growth of a transformed cell. Initial experiments targeting survivin with specific ribozymes or with antisense nucleotides, induced apoptosis in various cell-lines, or eliminated cisplatin resistance [89]. Based on these promising results, Isis Pharmaceuticals (http://www.isip.com) and Abbott Laboratories (http:// abbott.com) (Table 1) have launched the development of antisense-based strategies that target the expression of survivin [89].

\section{Concluding remarks}

The future of cancer therapy will be characterized by personalized treatment and the careful selection of therapeutic targets. Rapidly developing screening techniques, such as DNA microarrays, together with proteomics, will certainly help to achieve this goal. Advancements in oncogene-directed treatments using mechanisms of uncontrolled proliferation will require a better understanding of the numerous aberrations that contribute to the development of malignant diseases. The combination of agents that target different functions of a given oncoprotein complex or different physiological processes, such as differentiation and apoptosis (e.g. CD-437, TRAIL and chemotherapeutics), are expected to be more effective than single-agent protocols. Trials of multi-agent protocols without the need to test them individually should help to bring effective therapies into the clinic at a faster rate. In addition to the antisense and D-RNAi experiments mentioned here, the evaluation of small, interfering RNAs for gene silencing [90] could be important for diseases where aberrant gene-regulation plays a major role. A better understanding of the basis of cancer biology should yield drugs that target molecular or genetic aberrations in tumors. Such an endeavor will continue to expand in the coming decades and will be facilitated by knowledge from the Human Genome Project.

\section{Acknowledgements}

This work was supported by research grants: LO823/1-1 Deutsche Forschungsgemeinschaft (DFG), IZKF-E8, LO210110 Innovative Medizinische Forschung (IMF) and 01-1893-Lo I (Deutsche Krebshilfe), issued to M.L. We apologize to those authors whose work was not cited or discussed owing to space limitations.

\section{References}

1 Raff, M.C. (1992) Social controls on cell survival and cell death. Nature 356, 397-400

2 Vaux, D.L. and Korsmeyer, S.J. (1999) Cell death in development. Cell 96, 245-254

3 Sadowski-Debbing, K. et al. (2002) Caspases - their role in apoptosis and other physiological processes as revealed by knock-out studies. Arch. Immunol. Ther. Exp. 50, 19-34

4 Evan, G.I. and Vousden, K.H. (2001) Proliferation, cell cycle and apoptosis in cancer. Nature 411, 342-348

5 Reed, J.C. (2002) Apoptosis-based therapies. Nat. Rev. Drug Discov. $1,111-121$

6 Schattner, E.J. (2002) Apoptosis in lymphocytic leukemias and lymphomas. Cancer Invest. 20, 737-748

7 Stroh, C. et al. (2002) The role of caspases in cryoinjury: caspase inhibition strongly improves the recovery of cryopreserved hematopoietic and other cells. FASEB J. 16, 1651-1653

8 Yuan, J. et al. (1993) The C. elegans cell death gene ced-3 encodes a protein similar to mammalian interleukin-1b-converting enzyme. Cell 75, 641-652

9 Los, M. et al. (1999) The role of caspases in development, immunity, and apoptotic signal transduction: lessons from knockout mice. Immunity 10, 629-639

10 Reed, C.J. (2000) Apoptosis and cancer: strategies for integrating programmed cell death. Semin. Hematol. 37, 9-16

11 Pope, R.M. (2002) Apoptosis as a therapeutic tool in rheumatoid arthritis. Nat. Rev. Immunol. 2, 527-535

12 Srinivasula, S.M. et al. (2000) Molecular determinants of the caspasepromoting activity of Smac/DIABLO and its role in the death receptor pathway. J. Biol. Chem. 275, 36152-36157

13 Verhagen, A.M. et al. (2002) HtrA2 promotes cell death through its serine protease activity and its ability to antagonize inhibitor of apoptosis proteins. J. Biol. Chem. 277, 445-454

14 Huang, Y. et al. (2001) Structural basis of caspase inhibition by XIAP: differential roles of the linker versus the BIR domain. Cell 104, 781-790

15 Kischkel, F.C. et al. (1995) Cytotoxicity-dependent APO-1 (Fas/CD95)associated proteins form a death-inducing signaling complex (DISC) with the receptor. ЕMBO J. 14, 5579-5588

16 Slee, E.A. et al. (1999) Serial killers: ordering caspase activation events in apoptosis. Cell Death Differ. 6, 1067-1074

17 Wiley, S.R. et al. (1995) Identification and characterization of a new member of the TNF family that induces apoptosis. Immunity 3, 673-682

18 Walczak, H. et al. (1999) Tumoricidal activity of tumor necrosis factorrelated apoptosis- inducing ligand in vivo. Nat. Med. 5, 157-163

19 Ashkenazi, A. et al. (1999) Safety and antitumor activity of recombinant soluble Apo2 ligand. J. Clin. Invest. 104, 155-162

20 Wen, J. et al. (2000) Antileukemic drugs increase death receptor 5 levels and enhance Apo-2L-induced apoptosis of human acute leukemia cells. Blood 96, 3900-3906

21 Mori, S. et al. (1999) Sensitization of AIDS-Kaposi's sarcoma cells to Apo-2 ligand-induced apoptosis by actinomycin D. J. Immunol. 162, 5616-5623

22 Hernandez, A. et al. (2001) Sensitization of human colon cancer cells to TRAIL-mediated apoptosis. J. Gastrointest. Surg. 5, 56-65

23 Keane, M.M. et al. (1999) Chemotherapy augments TRAIL-induced apoptosis in breast cell lines. Cancer Res. 59, 734-741

24 Sun, S.Y. et al. (2000) Augmentation of tumor necrosis factor-related apoptosis-inducing ligand (TRAIL)-induced apoptosis by the synthetic retinoid 6-[3-(1-adamantyl)-4-hydroxyphenyl]-2-naphthalene carboxylic acid (CD437) through up-regulation of TRAIL receptors in human lung cancer cells. Cancer Res. 60, 7149-7155

25 Griffith, T.S. et al. (1998) Intracellular regulation of TRAIL-induced apoptosis in human melanoma cells. J. Immunol. 161, 2833-2840

26 Altucci, L. et al. (2001) Retinoic acid-induced apoptosis in leukemia cells is mediated by paracrine action of tumor-selective death ligand TRAIL. Nat. Med. 7, 680-686 
27 Bradbury, J. (2001) TRAIL leads to apoptosis in acute promyelocytic leukaemia. Lancet 357, 1770

28 Sun, S.Y. et al. (2000) Implication of multiple mechanisms in apoptosis induced by the synthetic retinoid CD437 in human prostate carcinoma cells. Oncogene 19, 4513-4522

29 Jo, M. et al. (2000) Apoptosis induced in normal human hepatocytes by tumor necrosis factor-related apoptosis-inducing ligand. Nat. Med. 6, 564-567

30 Nicholson, D.W. (1999) Caspase structure, proteolytic substrates, and function during apoptotic cell death. Cell Death Differ. 6, 1028-1042

31 Slee, E.A. et al. (1999) Ordering the cytochrome c-initiated caspase cascade: hierarchical activation of caspases-2, -3, -6, -7, -8, and -10 in a caspase-9-dependent manner. J. Cell Biol. 144, 281-292

32 Michalke, M. et al. (2001) The emerging role of caspases in signal transduction as revealed by knock-out studies - not only apoptosis. Signal. Transd. 2, 51-65

33 Los, M. et al. (2001) Caspases: more than just killers? Trends Immunol. $22,31-34$

34 Roy, S. et al. (2001) Maintenance of caspase-3 proenzyme dormancy by an intrinsic 'safety catch' regulatory tripeptide. Proc. Natl. Acad. Sci. U. S. A. 98, 6132-6137

35 Cursio, R. et al. (2000) Caspase inhibition protects from liver injury following ischemia and reperfusion in rats. Transpl. Int. 13, S568-S572

36 Mocanu, M.M. et al. (2000) Caspase inhibition and limitation of myocardial infarct size: protection against lethal reperfusion injury. Br. J. Pharmacol. 130, 197-200

37 Yaoita, H. et al. (1998) Attenuation of ischemia/reperfusion injury in rats by a caspase inhibitor. Circulation 97, 276-281

38 Daemen, M.A. et al. (1999) Inhibition of apoptosis induced by ischemia-reperfusion prevents inflammation. J. Clin. Invest. 104, 541-549

39 Pomerantz, B.J. et al. (2001) Inhibition of caspase 1 reduces human myocardial ischemic dysfunction via inhibition of IL-18 and IL-1 $\beta$. Proc. Natl. Acad. Sci. U. S. A. 98, 2871-2876

40 Kuida, K. et al. (1995) Altered cytokine export and apoptosis in mice deficient in interleukin-1 $\beta$ converting enzyme. Science 267, 2000-2003

$41 \mathrm{Li}$, P. et al. (1995) Mice deficient in IL-1 $\beta$-converting enzyme are defective in production of mature IL-1 $\beta$ and resistant to endotoxic shock. Cell 80, 401-411

42 Fantuzzi, G. et al. (1998) Interleukin-18 regulation of interferon gamma production and cell proliferation as shown in interleukin- $\beta$-converting enzyme (caspase-1)-deficient mice. Blood 91, 2118-2125

$43 \mathrm{Li}$, P. et al. (1997) Characterization of mice deficient in interleukin-1 $\beta$ converting enzyme. J. Cell Biochem. 64, 27-32

44 Norman, J. et al. (1997) Severity and mortality of experimental pancreatitis are dependent on interleukin-1 $\beta$ converting enzyme (ICE). J. Interferon Cytokine Res. 17, 113-118

45 Hotchkiss, R.S. et al. (2000) Caspase inhibitors improve survival in sepsis: a critical role of the lymphocyte. Nat. Immunol. 1, 496-501

46 Ayala, A. et al. (1996) Differential induction of apoptosis in lymphoid tissues during sepsis: variation in onset, frequency, and the nature of the mediators. Blood 87, 4261-4275

47 Wang, S.D. et al. (1994) Sepsis-induced apoptosis of the thymocytes in mice. J. Immunol. 152, 5014-5021

48 Miyashita, T. and Reed, J.C. (1993) Bcl-2 oncoprotein blocks chemotherapy-induced apoptosis in a human leukemia cell line. Blood 81, 151-157

49 McDonnell, T.J. et al. (1989) Bcl-2-immunoglobulin transgenic mice demonstrate extended B cell survival and follicular lymphoproliferation. Cell 57, 79-88

50 Adams, J.M. and Cory, S. (1998) The Bcl-2 protein family: arbiters of cell survival. Science 281, 1322-1326

51 Antonsson, B. and Martinou, J.C. (2000) The Bcl-2 protein family. Exp. Cell Res. 256, 50-57
52 Bouillet, P. et al. (2000) The role of the pro-apoptotic Bcl-2 family member bim in physiological cell death. Ann. N. Y. Acad. Sci. 926, 83-89

53 Reed, J.C. (1997) Double identity for proteins of the Bcl-2 family. Nature 387, 773-776

54 Kluck, R.M. et al. (1997) The release of cytochrome c from mitochondria: a primary site for Bcl-2 regulation of apoptosis. Science 275, 1132-1136

55 Yang, J. et al. (1997) Prevention of apoptosis by Bcl-2: release of cytochrome c from mitochondria blocked. Science 275, 1129-1132

56 Jurgensmeier, J.M. et al. (1998) Bax directly induces release of cytochrome c from isolated mitochondria. Proc. Natl. Acad. Sci. USA 95, 4997-5002

57 Stepczynska, A. et al. (2001) Staurosporine and conventional anticancer drugs induce overlapping, yet distinct pathways of apoptosis and caspase activation. Oncogene 20, 1193-1202

58 Rampino, N. et al. (1997) Somatic frameshift mutations in the BAX gene in colon cancers of the microsatellite mutator phenotype. Science 275, 967-969

59 Banerjee, D. (2001) Genasense (Genta Inc). Curr. Opin. Investig. Drugs 2, $574-580$

60 Nicholson, D.W. (2000) From bench to clinic with apoptosis-based therapeutic agents. Nature 407, 810-816

61 Lin, S.L. and Ying, S.Y. (2001) D-RNAi (messenger RNA-antisense DNA interference) as a novel defense system against cancer and viral infections. Curr. Cancer Drug Targets 1, 241-247

62 Chen, Y.G. et al. (2002) Regulation of cell proliferation, apoptosis, and carcinogenesis by activin. Exp. Biol. Med. (Maywood) 227, 75-87

63 Hamilton, A. and Piccart, M. (2000) The contribution of molecular markers to the prediction of response in the treatment of breast cancer: a review of the literature on HER-2, p53 and BCL-2. Ann. Oncol. 11, 647-663

64 O'Reilly, L.A. et al. (1996) The cell death inhibitor Bcl-2 and its homologues influence control of cell cycle entry. EMBO J. 15, 6979-6990

65 Brady, H.J. et al. (1996) Bax alpha perturbs T cell development and affects cell cycle entry of T cells. EMBO J. 15, 6991-7001

66 Mazel, S. et al. (1996) Regulation of cell division cycle progression by bcl-2 expression: a potential mechanism for inhibition of programmed cell death. J. Exp. Med. 183, 2219-2226

67 Konopleva, M. et al. (2000) Liposomal Bcl-2 antisense oligonucleotides enhance proliferation, sensitize acute myeloid leukemia to cytosinearabinoside, and induce apoptosis independent of other antiapoptotic proteins. Blood 95, 3929-3938

68 O'Connor, L. et al. (2000) Apoptosis and cell division. Curr. Opin. Cell Biol. 12, 257-263

69 Wang, J.L. et al. (2000) Structure-based discovery of an organic compound that binds Bcl-2 protein and induces apoptosis of tumor cells. Proc. Natl. Acad. Sci. U. S. A. 97, 7124-7129

70 Enyedy, I.J. et al. (2001) Discovery of small-molecule inhibitors of Bcl-2 through structure-based computer screening. J. Med. Chem. 44, 4313-4324

71 Peczuh, M.W. and Hamilton, A.D. (2000) Peptide and protein recognition by designed molecules. Chem. Rev. 100, 2479-2494

72 Cochran, A.G. (2001) Protein-protein interfaces: mimics and inhibitors. Curr. Opin. Chem. Biol. 5, 654-659

73 Zheng, T.S. et al. (1999) Caspase knockouts: matters of life and death. Cell Death Differ. 6, 1043-1053

74 Deveraux, Q.L. and Reed, J.C. (1999) IAP family proteins - suppressors of apoptosis. Genes Dev. 13, 239-252

75 Deveraux, Q.L. et al. (1998) IAPs block apoptotic events induced by caspase- 8 and cytochrome c by direct inhibition of distinct caspases. EMBO J. 17, 2215-2223

76 Kasof, G.M. and Gomes, B.C. (2001) Livin, a novel inhibitor of apoptosis protein family member. J. Biol. Chem. 276, 3238-3246

77 Deveraux, Q.L. et al. (1999) Cleavage of human inhibitor of apoptosis protein XIAP results in fragments with distinct specificities for caspases. EMBO J. 18, 5242-5251 
78 Sun, C. et al. (2000) NMR structure and mutagenesis of the third Bir domain of the inhibitor of apoptosis protein XIAP. J. Biol. Chem. 275, 33777-33781

79 Du, C. et al. (2000) Smac, a mitochondrial protein that promotes cytochrome c-dependent caspase activation by eliminating IAP inhibition. Cell 102, 33-42

80 Ekert, P.G. et al. (2001) DIABLO promotes apoptosis by removing MIHA/XIAP from processed caspase 9. J. Cell Biol. 152, 483-490

81 Liu, Z. et al. (2000) Structural basis for binding of Smac/DIABLO to the XIAP BIR3 domain. Nature 408, 1004-1008

82 Suzuki, Y. et al. (2001) A serine protease, HtrA2, is released from the mitochondria and interacts with XIAP, inducing cell death. Mol. Cell 8 , 613-621

83 Hegde, R. et al. (2002) Identification of Omi/HtrA2 as a mitochondrial apoptotic serine protease that disrupts inhibitor of apoptosis proteincaspase interaction. J. Biol. Chem. 277, 432-438

84 Tamm, I. et al. (1998) IAP-family protein survivin inhibits caspase activity and apoptosis induced by Fas (CD95), Bax, caspases, and anticancer drugs. Cancer Res. 58, 5315-5320

85 Li, F. et al. (1999) Pleiotropic cell-division defects and apoptosis induced by interference with survivin function. Nat. Cell Biol. 1, 461-466

86 Silke, J. and Vaux, D.L. (2001) Two kinds of BIR-containing protein inhibitors of apoptosis, or required for mitosis. J. Cell Sci. 114, 1821-1827

87 Speliotes, E.K. et al. (2000) The survivin-like C. elegans BIR-1 protein acts with the Aurora-like kinase AIR-2 to affect chromosomes and the spindle midzone. Mol. Cell 6, 211-223
88 Uren, A.G. et al. (1998) Conservation of baculovirus inhibitor of apoptosis repeat proteins (BIRPs) in viruses, nematodes, vertebrates and yeasts. Trends Biochem. Sci. 23, 159-162

89 Chen, J. et al. (2000) Down-regulation of survivin by antisense oligonucleotides increases apoptosis, inhibits cytokinesis and anchorage-independent growth. Neoplasia 2, 235-241

90 Tuschl, T. (2001) RNA interference and small interfering RNAs. Chembiochem. 2, 239-245

91 Hoglen, N.C. et al. (2001) Characterization of the caspase inhibitor IDN-1965 in a model of apoptosis-associated liver injury. J. Pharmacol. Exp. Ther. 297, 811-818

92 Jaeschke, H. et al. (2000) Protection against TNF-induced liver parenchymal cell apoptosis during endotoxemia by a novel caspase inhibitor in mice. Toxicol. Appl. Pharmacol. 169, $77-83$

93 Randle, J.C. et al. (2001) ICE/Caspase-1 inhibitors as novel antiinflammatory drugs. Expert Opin. Investig. Drugs 10, 1207-1209

94 Chi, K.N. et al. (2001) A phase I dose-finding study of combined treatment with an antisense Bcl-2 oligonucleotide (Genasense) and mitoxantrone in patients with metastatic hormone-refractory prostate cancer. Clin. Cancer Res. 7, 3920-3927

95 Adams, J. (2001) Proteasome inhibition in cancer: development of PS-341. Semin. Oncol. 28, 613-619

96 Sawyers, C.L. (2002) Rational therapeutic intervention in cancer: kinases as drug targets. Curr. Opin. Genet. Dev. 12, 111-115

97 Branton, P.E. and Roopchand, D.E. (2001) The role of adenovirus E4orf4 protein in viral replication and cell killing. Oncogene 20, $7855-7865$

\section{Drug Discovery Today online}

High quality printouts (from PDF files)

Links to other articles, other journals and cited software and databases

All you have to do is:

Obtain your subscription key from the address label of your print subscription

Go to http://www.drugdiscoverytoday.com

Click on the 'Claim online access' button

Click on the 'Personal Subscription Access' button

When you see the BioMedNet login screen, enter your BioMedNet username and password.

If you are not already a member please click on the 'Register' button to join.

You will then be asked to enter your subscription key.

Once confirmed you can view the full-text of Drug Discovery Today

If you get an error message please contact Customer Services (info@elsevier.com). If your institute is interested in subscribing to print and online please ask them to contact ct.subs@qss-uk.com 